\title{
ENHANCING ACADEMIC ACHIEVEMENT OF COMMERCE STUDENTS THROUGH BLENDED E-LEARNING
}

\author{
Ms. Sonu Bala Dhiman ${ }^{1}$ and Dr. Manju Gera ${ }^{2}$ 四 \\ ${ }^{1}$ Research Scholar, Department of Education, Panjab University, Chandigarh, India \\ ${ }^{2}$ Professor, Department of Education Usol, Panjab University, Chandigarh, India
}
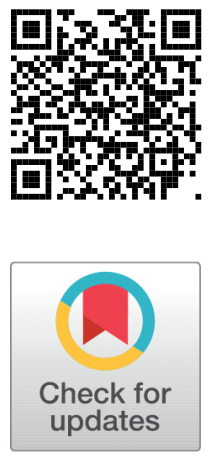

Received 6 July 2021

Accepted 15 July 2021

Published 31 July 2021

Corresponding Author

Ms. Sonu Bala Dhiman, Sonu.Dhim

an.212@Gmail.Com

DOI $10.29121 /$

granthaalayah.v9.i7.2021.4097

Funding: This research received no specific grant from any funding agency in the public, commercial, or not-for-profit sectors.

Copyright: (C) 2021 The Author(s). This is an open access article distributed under the terms of the Creative Commons Attribution License, which permits unrestricted use, distribution, and reproduction in any medium, provided the original author and source are credited.

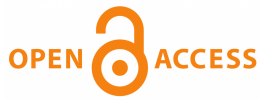

\section{ABSTRACT}

Blended e-learning is being adapted in education to enhance the students learning ability. Its contemporary methods of instruction, e-learning tools facilitate the enhancement of academic achievement of students and make them active participants in classroom. In the blended e-learning, various forms like video lessons, live online teaching, LMS (learning management system), e-books and supporting tools are used for effective and creative instructional processes. Using the Google Classroom with Google meet, five lessons of economics subject under CBSE, Delhi syllabus of XI Commerce class. The purpose of study was to enhance the academic achievement of XI Commerce students through blended e-learning in Economics. The sample of 60 students was taken from two CBSE affiliated private schools of Nangal, Punjab. The pre-test and posttest experimental design were used in the study. The data analysis showed higher academic achievement score of post-tests than the pre-test in economics. A significant difference between the mean scores of academic achievements in economics of pre-test and post-test was found. It can be inferred that blended e-learning enhances the academic achievement of Commerce students.

Keywords: Academic Achievement, Blended ELearning, Commerce Students

\section{INTRODUCTION}

The rapid progression of innovative technologies has transformed the education sector to a great extent. A well-built learning form has emerged that unites the finest features of two existing modes to eliminate the limitations of traditional teaching and online/e-learning and it is known as Blended E-learning. It is described as integrating face-to-face learning and electronic learning by using diverse learning theories, methodologies \& techniques in the same place and carrying out the learning with a variety of online technologies in the learning process in classroom. Blended learning unites the traditional face-to-face teaching and online learning Asarta and Schmidt (2017). In blended e-learning, the student's academic achievement enhances online 
as well as offline. McLaughlin et al. (2015) stated that enhanced student achievement in blended learning courses may be because students learn critical content online and utilize class time for their activities. Blended e-learning offer an immense effortlessness to achieve the course objectives by integrating the traditional teaching-learning with the e-learning elements. The academic achievement of students is an important aspect of educational processes at all level. Therefore, efforts need to be exerted to enhance the academic achievement of students by the use of highly interactive, creative and engaging form of delivering the content.

\section{SIGNIFICANCE OF STUDY}

Blended e-learning is an instructive form to deliver the content partly in normal teaching-learning mode and partly in electronic form. In blended e-learning the conventional setting remains static; but some of the content is carried out online. Implementing blended e-learning is an intricate process as the teachers have to decide the ideal blend of face-to-face and online learning activities while designing the courses. Blended e-learning utilizes technology to expand the students learning surroundings and let them become the active participants in the teaching-learning processes for enhancing their academic achievement. Therefore, this study was conducted on XI class Commerce Students in two CBSE affiliated private schools of Nangal, Punjab so as to enhance their academic achievement through blended e-learning.

\section{OBJECTIVES}

The objectives of the study were as follows:

- To study the effect of blended e-learning on academic achievement of students in economics.

- To study the effect of blended e-learning on academic achievement of students on the basis of gender.

\section{HYPOTHESIS}

Following was the hypothesis of the study:

- There exists no significant effect of blended e-learning on academic achievement of students in economics.

- There exists no significant difference between the academic achievement of boys' and girls' students in economics. 


\section{DELIMITATION OF STUDY}

The study was limited to -

- Two private schools of Nangal, Punjab.

- English medium CBSE affiliated schools.

- XI class Commerce students.

- Five lessons from Economics subject in XI class Commerce under CBSE syllabus.

\section{METHODOLOGY}

\section{- Sample of the Study}

For selecting the school sample of study, purposive random sampling technique was used. The two CBSE affiliated private schools of Nangal, Punjab were purposively chosen as they had the facility of computers; internet, whiteboard and projector. In both the schools, the intact commerce students were taken as sample of study. The description of sample of study is given in Figure 1 below.

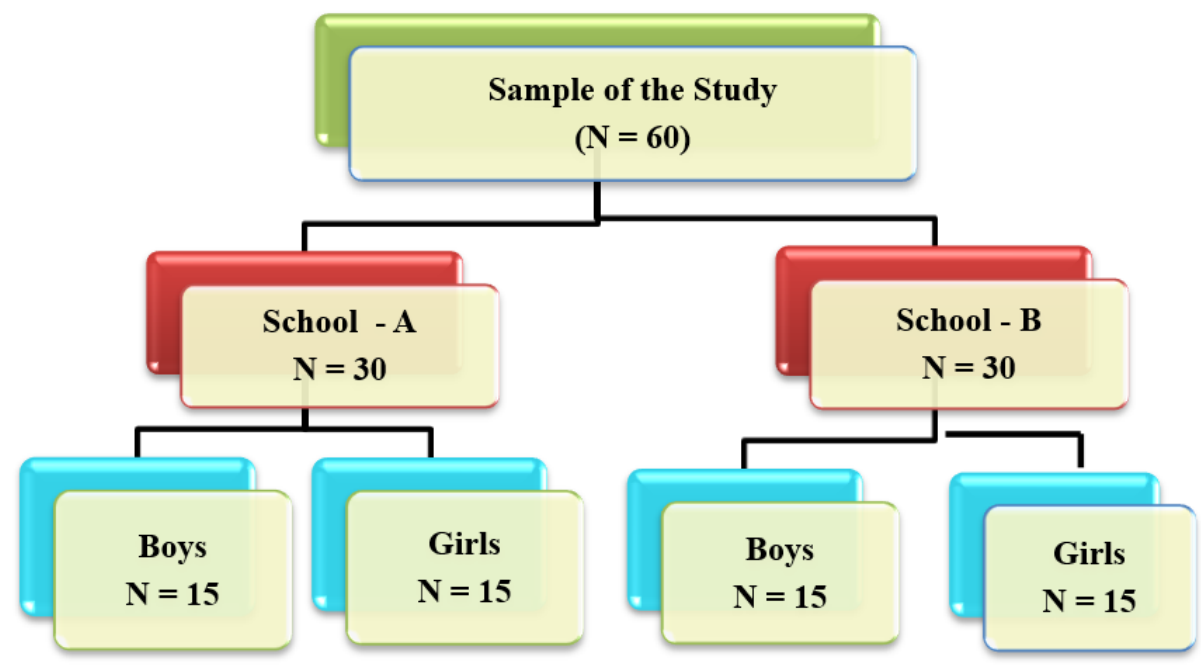

Figure 1 Sample of the Study

\section{- Design of the Study}

The pre-test and post-test experimental design were used for the study. There was only treatment group comprising of 60 students (i.e., 30 from each school). No control group was formed. The treatment group was administered the academic achievement test in economics as pre-test and post-test to evaluate their learning 
and understanding of content through blended e-learning. The students of XI Commerce class of two schools were taught five lessons of economics through blended e-learning. The design of study has been shown in Figure 2 .

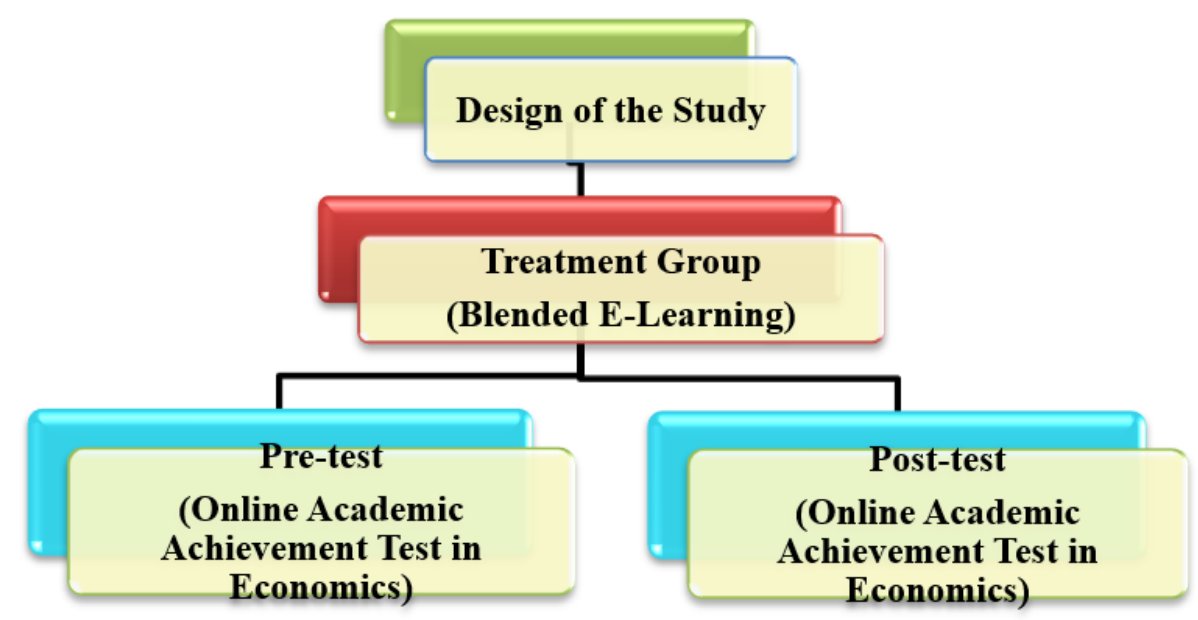

Figure 2 Design of the Study

\section{- Tools Used in the Study}

The researcher used the following tools, instructional materials and supporting services for conducting the study.

1. An academic achievement test in Economics. The test was of 50 marks (1 mark for each question) comprised 50 multiple choice questions framed from five chapters of economics subject in XI class Commerce under CBSE syllabus. To evaluate the academic achievement of XI Commerce students in economics, an online academic achievement test in economics was prepared in Google Form and shared with each student of treatment group through Google Classroom.

2. 10 Modules in Economics were prepared by researcher. For teaching the content to the treatment group, the modules were planned with different innovative methods, online activities, e-learning tools and techniques. In blended e-learning, some portion of content was taught via traditional mode and some in online mode.

3. Google Classroom, a free web service was used for carrying out the teachinglearning process through blended e-learning. For the Live online classes, Google meet app was used and link for scheduled classes were shared with all students through Google Classroom. 


\section{- Procedure}

For conducting the study, the researcher with the help of teachers from the chosen schools, selected the subject and number of lessons to be taught. On the basis of subject and content information, the researcher prepared 10 modules following the blended e-learning approach. An online academic achievement test in economics was prepared with 50 multiple choice questions. The students of treatment group were oriented about the experimentation through Google Classroom and Google meet. In blended e-learning, different online activities, online quiz, live chat, pre-recorded video lessons, live online class discussion, email, ppt, pdf documents and various other e-learning tools were used for collecting data, the researcher administered an online academic achievement pre-test on treatment group. After that, taught the students for one month. Then, after the experiment, an academic achievement post-test was administered to the treatment group.

\section{DATA ANALYSIS AND INTERPRETATION}

For analyzing the data, descriptive statistics was used where mean and standard deviation were calculated for the pre and post-test treatment group. The t-test was applied to find out the mean scores of academic achievements in economics between pre and post-test of treatment group. The results of analysis have been shown in Tables 1 and 2 respectively.

\begin{tabular}{|c|c|c|c|c|c|c|}
\hline Mode & $\begin{array}{l}\text { No. of } \\
\text { Students } \\
\text { (N) }\end{array}$ & Test & $\begin{array}{l}\text { Mean } \\
\text { Score }\end{array}$ & SD & 't' & $\begin{array}{c}\text { Significant } \\
\text { Level }\end{array}$ \\
\hline \multirow[t]{2}{*}{$\begin{array}{c}\text { Blended } \\
\text { E- } \\
\text { Learning }\end{array}$} & 60 & Pre-test & 25.04 & 6.06 & 8.74 & 0.05 \\
\hline & 60 & Post-test & 50.04 & 15.45 & & \\
\hline
\end{tabular}

The Table 1 analysis results have been shown in Figure 3 given below.

From the above Table 1 and Figure 3 , it is inferred that the post-test mean scores of blended e-learning is 50.04 which is higher than its pre-test means scores that is 25.4. The t-value (8.74) of pre and post-test in blended e-learning was found significant at the 0.05 level of significance. Thus, the null hypothesis: There exists no significant effect of blended e-learning on academic achievement of students in economics got rejected and research hypothesis got accepted. 


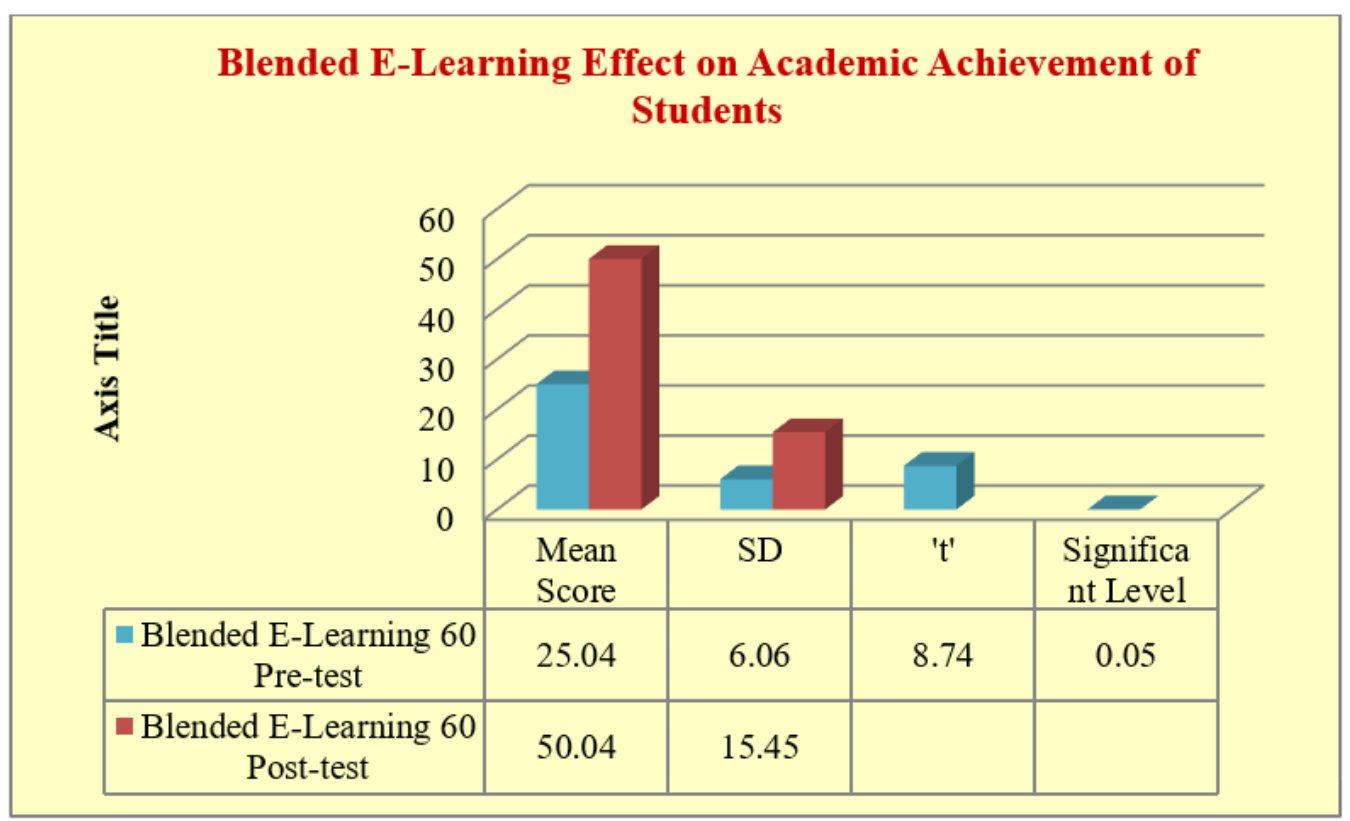

Figure 3 Significant Effect ofBlended E-Learning on Academic Achievement of Students in Economics

Table 2 Significant Difference between the Academic Achievement in Economics ofBoys and Girls Students in Blended E-Learning

\begin{tabular}{ccccccc|}
\hline Mode & $\begin{array}{c}\text { No. of } \\
\text { Students (N) }\end{array}$ & Gender & $\begin{array}{c}\text { Mean } \\
\text { Score }\end{array}$ & SD & 't' & $\begin{array}{c}\text { Significant } \\
\text { Level }\end{array}$ \\
$\begin{array}{c}\text { Blended } \\
\text { E- } \\
\text { Learning }\end{array}$ & 30 & Boys & 16.52 & 8.75 & 1.35 & 0.05 \\
\hline & 30 & Girls & 19.35 & 9.15 & \\
\hline
\end{tabular}

The Table 2 analysis results have been shown in Figure 4 given below.

From the above Table 2 and Figure 4 , it is inferred that the mean scores of girl students is 19.35 which is higher than the mean score of boy students that is 16.52 . The t-value (1.35) of mean difference between boys and girls was found insignificant at the 0.05 level of significance. Thus, the null hypothesis: There exists no significant difference between the academic achievement of boys and girl students in economics got accepted and the research hypothesis got rejected. 


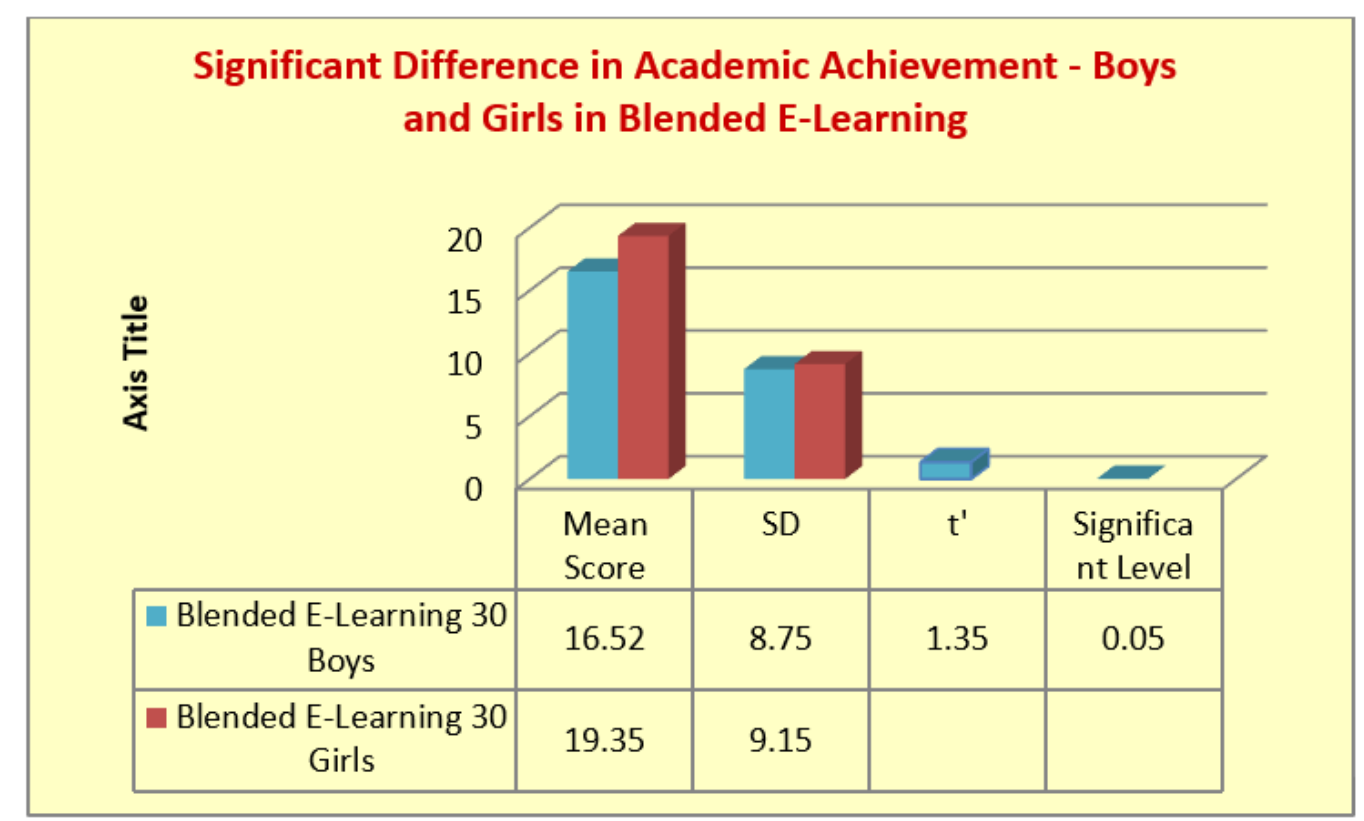

Figure 4 SignificantDifference between the Academic Achievement of Boys and Girls Students in Economics

\section{FINDINGS}

The main findings of the study are as follows -

- The post-test means scores of students'academic achievement in economics are at a higher level than the pre-test mean scores in blended e-learning.

- The blended e-learning instruction in Economics has positively enhanced the academic achievement of XI class Commerce students in economics subject.

\section{CONCLUSION}

In nutshell, it can be said that blended e-learning is the most effective ways of carrying instructional processes in today's time. Through blended e-learning, students can be actively engaged in learning online as well offline mode. The academic achievement of students can be well enhanced through blended e-learning innovative methodology and e-learning tools. Blended e-learning in an instructive form has been tested through a pre and post-test experiment on XI class Commerce students. Therefore, it has been concluded that blended e-learning helps in enhancing the academic achievement of Commerce students at school level. 


\section{REFERENCES}

Almasaeid, T. F. (2014). The Effect Of Using Blended Learning Strategy On Achievement And Attitudes In Teaching Science Among Grade 9th. European Scientific Journal, 10(31), 133-145.

Asarta, C. J., \& Schmidt, J. R. (2017). Comparing student performance in blended and traditional courses: Does prior academic achievement matter? The Internet and Higher Education, 32, 29-38. Retrieved from https://dx.doi.org/10.1016/j.iheduc.2016.08.002 10.1016/j.iheduc.2016.08.002

Ciftci, B. (2020). The Effect Of Blended Learning On Academic Achievement And Attitudes At Social Studies Courses. Open Journal For Educational Research, 4(2), 143-150.

McLaughlin, J. E., Gharkholonarehe, N., Khanova, J., Deyo, Z. M., \& Rodgers, J. E. (2015). The Impact of Blended Learning on Student Performance in a Cardiovascular Pharmacotherapy Course. American Journal of Pharmaceutical Education, 79(2), 24-24. Retrieved from https://dx.doi.org/10.5688/ajpe79224 10.5688/ajpe79224

Nachimuthu, K. (2020). Effectiveness Of Blended Learning For Degree Students. Journal of Critical Reviews, 7(15), 1440-1444.

Selvakumar, S., \& Sivakumar, P. (2019). The Impact Of Blended Learning Environment On Academic Achievement Of Engineering Students. International Journal Of Innovative Technology And Exploring Engineering, 8(12), 3782-3787. 